Georgia State University

ScholarWorks @ Georgia State University

7-31-2019

\title{
The Impact of Message Source on the Effectiveness of Communications About Climate Change
}

Toby Bolsen

Georgia State University, tbolsen@gsu.edu

Risa Palm

Georgia State University, risapalm@gsu.edu

Justin Kingsland

Georgia State University, jkingsland2@gsu.edu

Follow this and additional works at: https://scholarworks.gsu.edu/urban_studies_institute

Part of the Urban Studies and Planning Commons

\section{Recommended Citation}

Bolsen, Toby, Risa Palm, and Justin T. Kingsland. "The Impact of Message Source on the Effectiveness of Communications About Climate Change." Science Communication 41, no. 4 (August 2019): 464-87. https://doi.org/10.1177/1075547019863154.

This Article is brought to you for free and open access by the Urban Studies Institute at ScholarWorks @ Georgia State University. It has been accepted for inclusion in USI Publications by an authorized administrator of ScholarWorks @ Georgia State University. For more information, please contact scholarworks@gsu.edu. 


\title{
The Impact of Message Source on the Effectiveness of Communications about Climate Change
}

Toby Bolsen

\author{
Risa Palm
}

Justin T. Kingsland

\begin{abstract}
We conducted a survey experiment in which we presented 1,850 respondents with one of two versions of an appeal emphasizing either the threats to the environment or threats to national security of the United States as a result of climate change. The messages were attributed to one of four sources: Republican or Democratic party leaders, military officials, or climate scientists. The results reveal that messages attributed to military leaders, or to Republican party leaders, can enhance the impact of the appeal. This finding underscores the importance that the source of any communication can have on its overall effectiveness.
\end{abstract}

Keywords: Climate change, framing, message source, public opinion

Citation: Bolsen, T., Palm, R., \& Kingsland, J. T. (2019). The Impact of Message Source on the Effectiveness of Communications About Climate Change. Science Communication, 41(4), 464-487.

https://doi.org/10.1177/1075547019863154 
Americans report deep divisions along partisan lines over fundamental beliefs about whether human-caused climate change is real, the level of threat it poses, and whether there is a need for action to reduce greenhouse gases. Despite an overwhelming scientific consensus that climate change is human-caused and presents a major threat to human societies and ecosystems (Cook et al., 2016), a significant percentage of Americans do not believe that climate change is occurring (30\%) or that it is humancaused (42\%) (Leiserowitz et al., 2018; also see, Egan \& Mullins, 2017). Public discourse on climate change continues to be characterized by partisan and ideological divisions in the U.S. (Dunlap, McCright, \& Yarosh, 2016; Feldman et al., 2012; Hamilton, 2016; Hart et al., 2015). For example, one recent survey reported that while $95 \%$ of liberal Democrats believe that human-caused climate change is real, only $40 \%$ of conservative Republicans say the same (Goldberg et al., 2019; Leiserowitz et al., 2018). An important challenge for science communicators is how to effectively engage individuals who reject information about climate change.

Varying the way that climate change messages are framed - that is, varying the words, phrases or images that highlight specific aspects of climate change - has been shown to affect the response of various audiences (Feldman \& Hart, 2018; Lewandowsky, Gignac, \& Vaughan, 2013; McCright et al, 2016; Myers, Nisbet, Maibach, \& Leiserowitz, 2012; Nisbet \& Mooney, 2007; van der Linden, Leiserowitz, \& Maibach, 2019). For example, a communicator might bring attention to the environmental, economic, public health, or national security implications of climate change, providing an "interpretive storyline that set(s) a specific train of thought in 
motion, communicating why an issue might be a problem, who or what might be responsible for it, and what should be done about it" (Nisbet, 2009, p.15).

A growing body of research has examined how exposure to issue, or emphasis, frames shape climate change beliefs (for a review, see Bolsen \& Shapiro, 2017). Yet little work explicitly manipulates the source of an appeal focused on shifting public opinion on climate change. ${ }^{1}$ Are framed messages more impactful when they are associated with an ostensibly credible source? Does the presence of a partisan source manipulation (e.g., in-group versus out-group) condition the impact of the message?

We extend research on issue framing and social identity theory to generate predictions about how the presence of a source cue (climate scientists, military leaders, Democratic Party leaders, or Republican party leaders) in an appeal highlighting either the environmental or national security effects of climate change conditions the effectiveness of an appeal. We implemented a survey experiment to test how the presence of different sources conditioned a frame's impact on individuals' climate-related beliefs. The results suggest that the presence of specific sources linked with frames highlighting different effects of climate change can increase or decrease the message's impact on individuals' related beliefs. This underscores the importance that the source of any strategic climate communication effort can have on its overall effectiveness, as well as the need for credible and trusted opinion leaders to convey messages who have the capacity to persuade skeptical audiences.

\footnotetext{
1 We discuss several exceptions below, including Benegal \& Scruggs, 2018; Ehret, Van Boven, \& Sherman, 2018a; Van Boven, Ehret, \& Sherman, 2018b; Kousser \& Tranter, 2018.
} 


\section{Issue frames and climate change beliefs}

A growing body of research has explored how exposing people to frames that emphasize different aspects of climate change shape citizens' related beliefs and willingness to take actions that would reduce greenhouse gas emissions (Hart, 2011; Hart \& Feldman, 2016; Hart \& Nisbet, 2012; Maibach, Nisbet, Baldwin, Akerlof, \& Diao, 2010; Leiserowitz, 2007; Myers, Nisbet, Maibach, \& Leiserowitz, 2012; Nisbet, 2009; Villar \& Krosnick, 2011). An issue or emphasis framing effect occurs when exposure to a communication causes an individual to place relatively greater "weight" on the emphasized consideration in the opinion formation process (Chong \& Druckman, 2007). ${ }^{2}$

Exposure to framed messages may increase the availability, accessibility, and/or perceived applicability of specific aspects of the complicated issue of climate change. Myers et al. (2012), for instance, tested how exposure to one of three distinct frames associated with the effects of climate change - national security, environment, and public health - affected self-reported emotions among respondents with different levels of preexisting skepticism about climate change. They found that exposure to the public health frame increased feelings of hope whereas the national security frame unexpectedly increased anger among "doubtful" and "dismissive" audience segments. Myers et al.

\footnotetext{
${ }^{2}$ We focus exclusively on issue framing effects and not equivalency, or valence, framing effects that occur when positive or negative information unconsciously influences preferences as a result of a negativity bias in the encoding of stimulus information (Kahneman \& Tversky, 1979; for a typology of framing effects, see Levin, Schneider, \& Gaeth, 1998).
} 
(2012) stated that one factor that might have accounted for this "boomerang effect"3 was the lack of the congruence between the messenger and the frame. They posited that participants may have experienced anger at the experimenters for making claims about the national security implications of climate change, and called for future work to explore the role that the presence of sources linked with specific frames might have on different audiences.

Frames that accentuate scientific consensus among climate scientists regarding the existence of human-caused climate change have been found to increase belief in human-caused climate change and support among Americans for policy action to address the problem (Lewandowsky et al., 2012; van der Linden, 2015; van der Linden et al., 2019). Other studies have demonstrated that highlighting its local impacts, for instance through visual images showing flooding that would occur as a result of sea level rise in coastal communities, can increase public concern and support for actions to address the problem (Bolsen, Kingsland, \& Palm, 2018). However, response to otherwise credible and persuasive information can be undermined when presented in competition with rhetoric that politicizes climate science, for instance by actors seeking to cast doubt on the existence of a scientific consensus. (Bolsen \& Druckman, 2018; Druckman, 2017; McCright \& Dunlap, 2011; McCright et al., 2016; van der Linden et al., 2017).

\footnotetext{
${ }^{3}$ Hart and Nisbet (2012, p. 704) state, “A boomerang effect occurs when a message is strategically constructed with a specific intent but produces a result that is the opposite of that intent"; (for other examples of such effects in climate communication studies, see Cook \& Lewandowsky, 2016; Myers et al., 2012; Zhou, 2016).
} 


\section{Source credibility, trust, and persuasion}

While a number of experiments have documented the impact of exposure to strategic frames on Americans' climate beliefs, few studies have varied the presence of sources linked with a pro-climate action message to determine if such information moderates a frame's impact on individuals' climate beliefs. Research on environmental risk communication and issue-framing makes clear that the effectiveness of any message depends crucially on the audience's trust in and perception of credibility toward its source (Brewer \& Ley, 2013; Druckman, 2001a; 2001b; Liu \& Priest, 2009; Priest, 2001; Renn \& Levine, 1991). Perceptions about the competence, expertise, objectivity, impartiality, and fairness of a message's source determine its persuasive impact, as well as other more peripheral factors such as the attractiveness of the source, sympathy or empathy toward the source, and social status of the source (Renn \& Levine, 1991).

The "elaboration-likelihood model of persuasion" (ELM) has been applied by social scientists across disciplines to understand the mechanisms by which risk communication can generate persuasion (Petty \& Cacioppo, 1986). The ELM distinguishes between central and peripheral routes of persuasion. The peripheral route involves the use of heuristics - such as the perceived credibility of a messenger - in determining whether or not to accept a particular message; the central route is characterized by more effortful information processing triggered by the motivation of an individual to actively process the information (Brewer \& Ley, 2013; Eagly \& Chaiken, 1993; Renn \& Levine, 1991).

Finally, empirical research has demonstrated the credibility of "scientists" as generally credible sources. Surveys conducted in both the U.S. and among British 
citizens has demonstrated that "scientists" tend to be among the most trusted sources for providing accurate information about environmental issues in general and on climate change in particular (Bickerstaff et al., 2008; Malka, Krosnick, \& Langer, 2009; Nisbet \& Myers, 2007). ${ }^{4}$

Based on this literature, we hypothesize:

The presence of a credible source linked with a frame congruent with the expertise attributed to this source will increase the frame's impact on individuals' beliefs. Specifically, climate scientists linked with a frame highlighting climate change's environmental effects will increase the frame's impact on individuals' related beliefs. (Hypothesis 1)

Similarly, military leaders linked with a frame that emphasizes climate change's effects on U.S. national security will increase the frame's impact on individuals' related beliefs. (Hypothesis 2)

Social identity theory and climate change beliefs

People derive their self-concept, in part, from the social groups and categories to which they belong (Hogg \& Reid, 2006; Huddy, 2001; Huddy, Mason, \& Aaroe, 2015; Kahan, 2016). These group attachments play a powerful role in shaping determinations about the credibility and trust of any information source (Lenz, 2012; McCright,

\footnotetext{
${ }^{4}$ Partisanship, however, increasingly plays a role in perceptions about the credibility of scientific information (Benegal \& Scruggs, 2018; Gauchat, 2012; Motta, 2017), so it may be that on a polarized issue such climate change some groups (e.g., Republicans) may not find scientists to be the most effective source of any pro-climate appeal.
} 
Dentzman, Charters, \& Dietz, 2013; Renn \& Levine, 1991). Identity-based motivated reasoning can lead audiences to interpret information about climate change in a biased manner as a way to protect their existing beliefs or group attachments (Hart \& Nisbet, 2012; Kahan et al., 2011).

One form of protection of social identity is the use of partisan motivated reasoning (for a review, see Druckman, Leeper \& Slothuus, 2018; Taber \& Lodge, 2013; Kahan, 2015). This process can occur when people possess strong opinions that guide their reasoning strategies, or because of partisan cue-taking that simplifies and reduces the amount of information and effort necessary to form an opinion in a given context (Bartels, 2002; Bolsen, Druckman, \& Cook, 2014; Cohen, 2003; Goren et al., 2009; Guber, 2017; Kunda, 1990; Lelkes, Malka, \& Bakker, 2019; Malka \& Lelkes, 2010). Partisans in pursuit of value-affirming information may therefore turn to sources who share their group identity or cultural worldviews in seeking out or interpreting any new information about climate change (Benegal \& Scruggs, 2018; Feinberg \& Willer, 2013; Hmielowski et al., 2014; Kahan, Jenkins-Smith, \& Braman, 2011)

Perception of consensus, particularly within ones' close social network, also influences people to align their beliefs with what they perceive to be the majority pointof-view (Goldberg et al., 2019; Jost, 2018; van der Linden 2015). However, Americans tend to underestimate the actual level of social consensus about human-induced climate change (Mildenberger \& Tingley, 2017). Empirical research has identified the power of social consensus messages particularly among conservatives and Republicans. These groups show a stronger drive for conformity to in-group norms and greater willingness to adopt and share like-minded views with other Republicans (Benegal \& Scruggs, 2018; 
Goldberg et al., 2019; Jost, van der Linden, Panagopoulos \& Hardin, 2018). In a recent experiment that varied sources associated with a ballot proposal, Republicans were more likely to support a climate proposal when it was endorsed by Republican party elites, and perceptions that other Republicans also supported the initiative was a key mediating belief (Ehret, Van Boven, \& Sherman, 2018). In another recent study, a message sponsored by Republican senators led Republican respondents to reject misinformation about climate change, increase their belief in the existence of a scientific consensus, and increase their belief that it is human-caused (Benegal \& Scruggs, 2018). In these cases, the partisan membership of the person delivering the message plays a powerful role in the degree to which an appeal persuades any audience (Benegal \& Scruggs, 2018; Ehret, Van Boven, \& Sherman, 2018; Kousser \& Tranter, 2018; Li et al., 2016; Maibach et al., 2015; Van Boven, Ehret, \& Sherman, 2018).

Based on the findings of these studies, we hypothesize that:

The presence of an in-group (i.e., in-partisan) source regardless of the frame with which it is associated will increase the frame's impact on in-partisans' related beliefs.

\section{(Hypothesis 3)}

\section{Data and methodology}

We conducted a survey of 1,850 unique respondents recruited using Amazon's Mechanical Turk (MTurk) service in July 2018. ${ }^{5}$ Each participant was randomly

\footnotetext{
${ }^{5}$ MTurk samples offer greater diversity than student or other convenience samples and have been used to replicate numerous studies across disciplines (Berinsky et al., 2012;
} 
assigned to one of ten conditions that varied the content of an appeal accentuating either the environmental or national security risks of climate change (i.e., environmental or national security frame). Two treatments were defined: one based on the threat that climate change poses to the national security of the United States, and the second that climate change poses for environmental sustainability. The national security treatment emphasized the effects of climate change on human migration patterns and potential "conflict over land ownership or water use that could result in war," while the environmental treatment emphasized coastal flooding due to sea-level rise and an increased frequency of droughts and wildfires. In addition to highlighting these effects, both treatments advocated action "to promote energy efficiency and renewable energy to substantially decrease our greenhouse gas emissions.." ${ }^{\circ 6}$ We selected the environmental frame given its dominance in climate discourses and the national security frame given the and the call to link it with a credible source (e.g., Myers et al., 2012). The frames also matched the domain of expertise for two of the sources we manipulated in the study.

To test the impact of the source, we assigned respondents to one of five groups. For instance, the headline above the article in the no source (baseline) condition stated, "Call for Action on Climate" and did not explicitly mention a source, whereas the other conditions linked the appeal to a specific source - e.g., "Climate Scientists, Republican Party Leaders, Democratic Party Leaders, or Military Leaders.” The appeal itself stated

Mullinix et al., 2015). Descriptive statistics for the sample are available in a supplementary file available upon request.

${ }^{6}$ The complete wording of the stimuli for each condition and the survey instrument is available upon request. 
that "Democratic Party leaders," "Republican Party leaders," "military leaders," or "climate scientists" were the ones highlighting these effects of climate change and calling for policy action to reduce greenhouse gas emissions.

We measured how exposure to the treatments affected individuals' beliefs about: (a) the level of threat that climate change presents to national security (1-5 scale, none at all / a great deal); (b) the level of threat that climate change presents to a sustainable environment (1-5 scale, none at all / a great deal); and, (c) support for laws that promote energy efficiency and renewable energy as a way to combat climate change (1-7 strongly oppose / strongly support). The information that was employed across experimental conditions highlighted one of these threats and called for a greater reliance on renewable energy. As such, these measures serve as our primary dependent variables to evaluate how message sources condition an appeal's impact.

We also included several additional post-treatment measures. First, we measured fundamental beliefs about climate change: (d) whether or not they believe climate change is happening (1-7 Definitely not happening / definitely happening) and (e) the extent to which they agreed with a statement that a scientific consensus exists regarding climate change happening primarily as a result of human activity (1-7 strongly disagree / strongly agree). Because our experiment explicitly manipulated the source of the message highlighting the threats of climate change and need for policy action, we measured respondents' perceptions about (f) the degree to which political motives are a driver of scientific research on climate change (1-7 strongly disagree / strongly agree). We anticipate that audiences predisposed toward climate skepticism (e.g., Republicans) may view messages from in-group sources about climate change as "less politicized" 
compared to the same message without a source (or when attributed to an out-party leader). Last, we measured respondents' agreement with the statement (g) that the idea climate change is primarily due to human activity is a hoax or a conspiracy (1-7 strongly disagree / strongly agree). We included this item given the literature showing that motivated reasoning processes appear to drive the expression of this relatively widespread belief held by many Americans (i.e., estimated between 20\%-40\%) regarding climate change (e.g., see Miller, Saunders, \& Farhart, 2016; Uscinski, Klofstad, \& Atkinson, 2016; Uscinski \& Parent, 2014). We anticipate similar dynamics resulting from the source manipulation on climate hoax belief as with the other key measures - i.e., credible sources, or in-group/out-group sources, linked to an appeal highlighting the threats of climate change will condition the impact of each message. Although belief in conspiracies is a general predisposition (Lewandowsky, Oberauer, \& Gignac, 2013; Oliver \& Wood, 2014), political ideology is strongly associated with which conspiracies an individual will endorse (Uscinski \& Parent, 2014). We expect that in-group sources linked with a message highlighting climate change's threats will decrease climate hoax beliefs, whereas out-group sources may increase such beliefs among skeptical audiences (i.e., Republicans who receive a message sponsored by Democratic Party leaders) as a result of partisan motivated reasoning. We measured party identification on a 7-point Likert scale, and then created a series of dummy variables for respondents who identified as Democrat, Independent, or Republican.

Before turning to the results of our analyses, we include a condensed description of our research design. Table 1 presents the framework of our experimental design, a 
description of the treatments provided to respondents in each condition, and a restatement of our hypothesized expectations.

\section{[Insert Table 1 here]}

\section{Results}

We evaluate the impact of the experimental treatments by regressing each dependent variable on the experimental conditions, omitting the no-source appeal as the baseline for each distinct appeal. ${ }^{7}$ Our design allows us to evaluate the effects of the presence of two ostensibly credible, "expert" sources associated with each frame as well as the impact of Republican and Democratic Party leaders.

The first column in Figure 1 reports the impact of the experimental conditions on belief that climate change presents a threat to U.S. national security. First, in support of Hypothesis 1, military leaders as the source of the message emphasizing climate change's threats to national security significantly increase the belief that climate change is a national security threat across all respondents in the sample relative to the no-source baseline $(p=.04)$. We did not anticipate any effect of military leaders as the source of the environmental message (Column 2, Figure 1) on beliefs that climate change presents a threat to national security; however, as Figure 1 reports, military leaders linked with this frame also significantly increased beliefs that climate change is a threat to national security relative the no-source baseline $(p=.01)$. Military leaders did not have an effect on perceptions about the degree to which climate change presents an environmental threat

\footnotetext{
${ }^{7}$ We report the means and standard deviations for each condition across all of the dependent variables in a supplementary file available upon request from the corresponding author.
} 
relative to the no-source baseline for that message. This suggests that the impact of a source may depend on the degree to which the belief measured is in a domain in which the source is perceived as an expert. Interestingly, in the full sample, military leaders linked with a national security frame had no effect on support for a greater reliance on renewable energy to reduce greenhouse gas emissions (Support Laws), as well as other beliefs we measured such as the belief climate change is happening, that a scientific consensus exists, or that climate change is a hoax.

\section{[Insert Figure 1 here]}

The right side of Figure 1 reports the effects of the experimental conditions on respondents' belief that climate change presents a threat to a sustainable environment. Hypothesis 2 predicted that climate scientists linked with an environmental message would increase this message's impact relative to the no source baseline. We find no support for this hypothesis. We also find that when climate scientists are the source of a message about the threat that climate change presents to national security and linked with a call for policy action, respondents significantly reduced the strength of their beliefs about the environmental threat climate change poses $(p=.03)$, support for laws to promote renewable energy $(p=.04)$, belief that climate change is happening $(p=.01)$, and belief that a scientific consensus exists $(p=.01)$.

The effects are even more dramatic when partisan information sources are compared with the no-source baseline on the full sample. First, when Republican Party leaders are the source of the national security climate message, respondents increase their support for polices that would promote renewable energy to reduce greenhouse gases (Support Laws) $(p=.08)$. Republican sources linked with a national security 
message reduced the perception that climate change research is driven primarily by political motivations $(p=.01)$. Further, Republican sources linked with this frame and call for action also significantly decreased respondents' perception that human induced climate change is a hoax by nearly a one-half point shift on the five-point response scale $(p=.02)$. Source effects were more prominent in the national security frame conditions compared to the environmental frame conditions. Nonetheless, when the environmental message was attributed to Republican sources, respondents' perceptions that a scientific consensus exists on human-caused climate change increases $(p=.09)$. On the other hand, when the source of the national security message and call for action is attributed to Democratic leaders, respondents became significantly less likely to see climate change as a security threat $(p=.10)$ and significantly less likely to say that climate change is occurring $(p=.03)$ or that a scientific consensus exists $(p=.06)$.

To evaluate Hypothesis 3 regarding how in-group versus out-group partisan sources may condition the impact of the experimental conditions on our dependent measures, we replicate the analyses separately for Republican and Democrats in our sample. ${ }^{8}$ First, we found very few significant treatment effects resulting from the source manipulations when comparing Democrats in the no-source baseline condition to

\footnotetext{
${ }^{8}$ We chose this modeling approach rather than testing models with interaction effects because we are interested (theoretically) in testing for source-effects associated with the frames we introduce on Democrats (Republicans) in each condition relative to Democrats (Republicans) in the No-Source baseline condition to examine within-subgroup effects. We lack clear theoretical expectations for other estimation approaches that would rely on Independents in the No-Source condition as a baseline for our hypothesis tests.
} 
Democrats across all other conditions (see Table 2 and Figure 2). There are a few exceptions, such as military leaders having a significant positive effect on Democrats' perceptions climate change is a national security threat, but the overall picture is that Democrats in the baseline condition (and all source conditions) report highly skewed beliefs that resulted in ceiling effects with little room for additional movement on many of the response scales.

\section{[Insert Table 2 and Figure 2 here]}

Republicans tend to be more skeptical about climate change and less supportive of laws to reduce greenhouse gases. However, we find that when Republican Party leaders are the source of the environmental threat message, Republican respondents significantly increased their belief that climate change is an environmental threat (Table 3, Model 2, $p$ $=.03$ ), that a scientific consensus exists (Table 3, Model $6, p=.04$ ), and support for polices that would increase a reliance on renewable energy to decrease greenhouse gas emissions (Table 3, Model 4, $p=.09$ ). When Republican Party leaders are linked with the national security message it significantly reduced Republicans' perceptions that climate change research is politically motivated by nearly a full point on the response scale (Table 3, Model 1, $p=.01$ ) and decreased perceptions among Republicans that evidence regarding climate change is a conspiracy or hoax (Table 3, Model 1, $p=.09$ ).

\section{[Insert Table 3 here]}

On the other hand, we find that when Democratic Party leaders are linked with the environmental threat appeal, Republican respondents report significantly greater perceptions that climate change research is politically motivated (Table 3, Model 1, $p=$ 
.05 ), and become significantly more convinced that climate change a hoax (Table 3 , Model $1, p=.05$ ). In contrast, when Republican Party leaders are associated with the national security message, Republican respondents were significantly less likely to perceive climate science research as driven by political motivations (Table 3, Model 1, $p$ $=.01)$.

\section{Discussion and Conclusions}

The U.S. public remains polarized along partisan and ideological lines on the issue of human-induced climate change. Science communicators and others who seek to build greater consensus thus face challenges both in securing the public's attention to important information (Lupia, 2013), as well as motivating skeptical audiences to evaluate information in an "even-handed" manner with the goal of arriving at an “accurate," or correct, conclusion (Druckman, 2013; Druckman \& Lupia, 2017).

We investigated an approach to communicating information about climate change that involved manipulating the source of a message, while holding the content of the message constant. We find that the presence of military leaders as a source of a proclimate appeal can significantly strengthen its persuasive impact, especially in the case of an appeal emphasizing the effects of climate change on U.S. national security.

Republican Party leaders also enhanced the effectiveness of a frame both on average and among in-group respondents, perhaps due to the surprising effect that unconventional or unexpected sources of information can have in terms of its persuasive impact. Partisans making statements that do not align with their perceived group's position may draw greater attention to the frame's content, may be seen as a "costly" signal thereby enhancing its perceived honesty and credibility, or may reduce identity protective forms 
of motivated reasoning that would otherwise lead to the rejection of arguments related to a polarized and highly salient issue such as climate change (Bengal \& Scruggs, 2018;

Druckman \& McGrath, 2019; Kahan et al., 2011; Kahan, 2015).

On the other hand, we found a perhaps surprising impact of one information source: climate scientists. When climate scientists were linked with the national security message it significantly reduced respondents' perceptions about the threat of climate change to national security, support for policy action, and perceptions of a scientific consensus. Indeed when messages were attributed to climate scientists, they either had no effect on most of the variables we tested, or their effect was a negative one. The call by the American Meteorological Society for more engagement in policy communication by climate scientists (https://amspolicyforum.org/index.cfm/amspolicyforum/), suggests the need for more interdisciplinary communication between climate scientists and those who study the efficacy of message communication. Dissonant science messages may threaten in-group identity (Dixon, Hmielowski, \& Ma, 2017), leading to resistance and a greater distrust and negative affect toward scientists, and less support for action to address climate change (Dixon \& Huber, 2018; Nisbet et al., 2015). Targeted frames, however, that emphasize free-market solutions have been found to increase acceptance of climate science among conservatives (Campbell \& Kay, 2014; Dixon et al., 2017).

We also find that there are circumstances under which skeptical audiences will be more open to climate change policy information. Republicans who received an environmental threat message sponsored by Republican Party leaders increased the strength of their belief that climate change poses a threat to sustainable environment, their support for laws to reduce greenhouse gas emissions, and their beliefs that a scientific 
consensus exists regarding human activities being the primary cause of climate change. Similarly, Republicans who received a national security threat message sponsored by Republican Party leaders were less likely to state that climate change research is driven by political considerations, and reported significantly lower perceptions that climate change is a conspiracy or hoax. This clearly demonstrates the power that trusted in-group (i.e., in-party leaders) sources could play in overcoming hurdles posed by partisan polarization on climate change. On the other hand, we find that when the source of the environmental threat message is Democratic Party leaders, Republicans become significantly more likely to report that climate change research is driven by political motivations and more likely to say that climate change is a hoax. The source of an identical appeal thus has a powerful impact on how the information affects individuals' beliefs not only about the threats that climate change presents and willingness to support policy action, but also on broader perceptions about the motivations of climate change research, and even beliefs that climate change is a hoax. This is a finding that should prompt further exploration.

Future research should also explore the generalizability of our findings and the impact of varied sources associated with climate change information across different populations and using different content messages (e.g., highlighting the source of information on scientific consensus reports or public health considerations). The results we report are encouraging insofar as we show that sources perceived to be credible and trusted and that deliver climate change messages to skeptical audiences can break through the barriers that impede communication efforts. 
This paper highlights the role that credible sources can play in shaping skeptical audiences views about climate change and overcoming partisan barriers that impede efforts to generate greater consensus among the U.S. public. The finding that Republican Party leaders, and military leaders, had the strongest effect, on average, at enhancing the framed messages suggests that source credibility may increase when an "unconventional" position is taken by group leaders (Prior, Partridge, \& Plant, 2014). The finding that climate scientists had little effect, or at worst a negative effect, also needs further attention. More exploration is necessary to understand the efficacy of source credibility linked with distinct arguments on climate change as well as the duration and persistence of efforts to overcome polarization and foster consensus and climate engagement. 


\section{References}

Bartels, L. M. (2002). Beyond the running tally: Partisan bias in political perceptions. Political Behavior, 24(2), 117-150.

Benegal, S. D., \& Scruggs, L. A. (2018). Correcting misinformation about climate change: the impact of partisanship in an experimental setting. Climatic Change, 148(1-2), 61-80.

Berinsky, A. J., Huber, G. A., \& Lenz, G. S. (2012). Evaluating online labor markets for experimental research: Amazon. com's Mechanical Turk. Political Analysis, 20(3), 351-368.

Bickerstaff, K., Lorenzoni, I., Pidgeon, N. F., Poortinga, W., \& Simmons, P. (2008). Reframing nuclear power in the UK energy debate: nuclear power, climate change mitigation and radioactive waste. Public Understanding of Science, 17(2), 145169.

Bolsen, T., \& Druckman, J. N. (2018). Do partisanship and politicization undermine the impact of a scientific consensus message about climate change? Group Processes \& Intergroup Relations, 21(3), 389-402.

Bolsen, T., Druckman, J. N., \& Cook, F. L. (2014). The influence of partisan motivated reasoning on public opinion. Political Behavior, 36(2), 235-262.

Bolsen, T., Kingsland, J., \& Palm, R. (2018). The impact of frames highlighting coastal flooding in the USA on climate change beliefs. Climatic Change, 147(1-2), 359368.

Bolsen, T., \& Shapiro, M.A. (2017). Strategic framing and persuasive messaging to influence climate change perceptions and decisions. Oxford Research Encyclopedia of Climate Science. DOI:10.1093/acrefore/9780190228620.013.435

Brewer, P. R., \& Ley, B. L. (2013). Whose science do you believe? Explaining trust in sources of scientific information about the environment. Science Communication, 35(1), 115-137.

Campbell, T. H., \& Kay, A. C. (2014). Solution aversion: On the relation between ideology and motivated disbelief. Journal of Personality and Social Psychology, 107(5), 809-824.

Chong, D., \& Druckman, J. N. (2007). Framing theory. Annual Review of Political Science, 10,103-126.

Cohen, G. L. (2003). Party over policy: The dominating impact of group influence on political beliefs. Journal of Personality and Social Psychology, 85(5), 808-822. 
Cook, J., \& Lewandowsky, S. (2016). Rational irrationality: Modeling climate change belief polarization using Bayesian networks. Topics in Cognitive Science, 8(1), 160-179.

Cook, J., Oreskes, N., Doran, P. T., Anderegg, W. R., Verheggen, B., Maibach, E. W., ... $\&$ Nuccitelli, D. (2016). Consensus on consensus: a synthesis of consensus estimates on human-caused global warming. Environmental Research Letters, 11(4), 048002.

Dixon, G., Hmielowski, J., \& Ma, Y. (2017). Improving climate change acceptance among US conservatives through value-based message targeting. Science Communication, 39(4), 520-534.

Dixon, G., \& Hubner, A. (2018). Neutralizing the effect of political worldviews by communicating scientific agreement: A thought-listing study. Science Communication, 40(3), 393-415.

Druckman, J. N. (2001a). On the limits of framing effects: Who can frame? Journal of Politics, 63(4), 1041-1066.

Druckman, J. N. (2001b). Using credible advice to overcome framing effects. Journal of Law, Economics, and Organization, 17(1), 62-82.

Druckman, J. N. (2013). Public opinion: Stunted policy support. Nature Climate Change, 3(7), 617.

Druckman, J. N., Leeper, T. J., \& Slothuus, R. (2018). Motivated responses to political communications: framing, party cues, and science information. In Lavine, H.G., Taber, C.S. (eds.) The Feeling, Thinking Citizen: Essays in Honor of Milton Lodge. New York: Routledge.

Druckman, J. N. (2017). The crisis of politicization within and beyond science. Nature Human Behaviour, 1(9), 615.

Druckman, J. N., \& Lupia, A. (2017). Using frames to make scientific communication effective. In D. Scheufele, D.M. Kahan, K.H. Jamieson, (Eds.), Handbook of the Science of Science Communication (pp. 13-31). New York, NY: Oxford University Press.

Druckman, J. N., \& McGrath, M. C. (2019). The evidence for motivated reasoning in climate change preference formation. Nature Climate Change, 9(2), 111-119.

Dunlap, R. E., McCright, A. M., \& Yarosh, J. H. (2016). The political divide on climate change: Partisan polarization widens in the US. Environment: Science and Policy for Sustainable Development, 58(5), 4-23. 
Eagly, A. H., \& Chaiken, S. (1993). The psychology of attitudes. Harcourt Brace Jovanovich College Publishers.

Egan, P. J., \& Mullins, M. (2017). Climate change: US public opinion. Annual Review of Political Science, 20, 209-227.

Ehret, P. J., Van Boven, L., \& Sherman, D. K. (2018). Partisan Barriers to Bipartisanship: Understanding Climate Policy Polarization. Social Psychological and Personality Science, 9(3), 308-318.

Feinberg, M., \& Willer, R. (2013). The moral roots of environmental attitudes. Psychological Science, 24(1), 56-62.

Feldman, L., \& Hart, P.S. (2018). Is there any hope? How climate change news imagery and text influence audience emotions and support for climate mitigation policies. Risk Analysis, 38(3), 585-602.

Feldman, L., Maibach, E. W., Roser-Renouf, C., \& Leiserowitz, A. (2012). Climate on cable: The nature and impact of global warming coverage on Fox News, CNN, and MSNBC. The International Journal of Press/Politics, 17(1), 3-31.

Gauchat, G. (2012). Politicization of science in the public sphere: A study of public trust in the United States, 1974 to 2010. American Sociological Review, 77(2), 167187.

Goldberg, M., van der Linden, S., Leiserowitz, A., \& Maibach, E. (2019). Perceived Social Consensus Can Reduce Ideological Biases on Climate Change. Environment and Behavior https://doi.org/10.17863/CAM.37992.

Goren, P., Federico, C. M., \& Kittilson, M. C. (2009). Source cues, partisan identities, and political value expression. American Journal of Political Science, 53(4), 805820.

Guber, Deborah Lynn. (2017). Partisan cueing and polarization in public opinion about climate change. Oxford Research Encyclopedia of Climate Science. doi: https://dx.doi.org/10.1093/acrefore/9780190228620.013.306.

Hamilton, L. C. (2016). Public awareness of scientific consensus on climate. Sage Open, doi: $10.1177 / 2158244016676296$.

Hamilton, L. C. (2011). Education, politics and opinions about climate change evidence for interaction effects. Climatic Change, 104(2), 231-242. 
Hart, P. S., \& Nisbet, E. C. (2012). Boomerang effects in science communication: How motivated reasoning and identity cues amplify opinion polarization about climate mitigation policies. Communication Research, 39(6), 701-723.

Hart, P. S. (2011). One or many? The influence of episodic and thematic climate change frames on policy preferences and individual behavior change. Science Communication, 33(1), 28-51.

Hart, P. S., \& Feldman, L. (2016). The impact of climate change-related imagery and text on public opinion and behavior change. Science Communication, 38(4), 415441.

Hart, P. S., \& Feldman, L. (2014). Threat without efficacy? Climate change on US network news. Science Communication, 36(3), 325-351.

Hart, P. S., Feldman, L., Leiserowitz, A., \& Maibach, E. (2015). Extending the impacts of hostile media perceptions: influences on discussion and opinion polarization in context of climate change. Science Communication, 37(4), 506-532.

Hmielowski, J. D., Feldman, L., Myers, T. A., Leiserowitz, A., \& Maibach, E. (2014). An attack on science? Media use, trust in scientists, and perceptions of global warming. Public Understanding of Science, 23(7), 866-883.

Hogg, M. A., \& Reid, S. A. (2006). Social identity, self-categorization, and the communication of group norms. Communication Theory, 16(1), 7-30.

Huddy, L. (2001). From social to political identity: A critical examination of social identity theory. Political Psychology, 22(1), 127-156.

Huddy, L., Mason, L., \& Aarøe, L. (2015). Expressive partisanship: Campaign involvement, political emotion, and partisan identity. American Political Science Review, 109(1), 1-17.

Jost, J. T. (2018). Underestimating belief in climate change. Nature Climate Change, 8(3), 189.

Jost, J. T., van der Linden, S., Panagopoulos, C., \& Hardin, C. D. (2018). Ideological asymmetries in conformity, desire for shared reality, and the spread of misinformation. Current Opinion in Psychology, 23, 77-83.

Kahan, D. M. (2015). Climate-science communication and the measurement problem. Political Psychology 36, 1-43.

Kahan, D. M. (2016). The Politically Motivated Reasoning Paradigm, Part 1: What Politically Motivated Reasoning Is and How to Measure It. In Emerging Trends in 
the Social and Behavioral Sciences (eds R. A. Scott and S. M. Kosslyn). doi:10.1002/9781118900772.etrds0417

Kahan, D. M., Jenkins-Smith, H., \& Braman, D. (2011). Cultural cognition of scientific consensus. Journal of Risk Research, 14(2), 147-174.

Kahan, D. M., Peters, E., Wittlin, M., Slovic, P., Ouellette, L. L., Braman, D., \& Mandel, G. (2012). The polarizing impact of science literacy and numeracy on perceived climate change risks. Nature Climate Change, 2(10), 732.

Kousser, T., \& Tranter, B. (2018). The influence of political leaders on climate change attitudes. Global Environmental Change, 50, 100-109, doi: 10.1016/j.gloenvcha.2018.03.005.

Kunda, Z. (1990). The case for motivated reasoning. Psychological Bulletin, 108(3), 480.

Leiserowitz, A. (2007). Communicating the risks of global warming: American risk perceptions, affective images, and interpretive communities. In S.C. Moser, L. Dilling (Eds.), Creating a climate for change: Communicating Climate Change and Facilitating Social Change, (pp. 44-63). Cambridge: Cambridge University Press.

Leiserowitz, A., Maibach, E., Roser-Renouf, C., Rosenthal, S., Cutler, M., \& Kotcher, J. (2018). Climate change in the American mind: march 2018. Yale University and George Mason University. New Haven (CT): Yale Program on Climate Change Communication.

Lelkes, Y., Malka, A., \& Bakker, B. N. (2018). An expressive utility account of partisan cue receptivity: Cognitive resources in the service of identity expression. Unpublished manuscript.

Lenz, G. S. (2012). Follow the leader?: how voters respond to politicians' policies and performance. Chicago: University of Chicago Press.

Levin, I. P., Schneider, S. L., \& Gaeth, G. J. (1998). All frames are not created equal: A typology and critical analysis of framing effects. Organizational Behavior and Human Decision Processes, 76(2), 149-188.

Lewandowsky, S., Oberauer, K., \& Gignac, G. E. (2013). NASA faked the moon landing - therefore,(climate) science is a hoax: An anatomy of the motivated rejection of science. Psychological Science, 24(5), 622-633.

Lewandowsky, S., Gignac, G. E., \& Vaughan, S. (2013). The pivotal role of perceived scientific consensus in acceptance of science. Nature Climate Change, 3(4), 399. 
Li, N., Hilgard, J., Scheufele, D. A., Winneg, K. M., \& Jamieson, K. H. (2016). Crosspressuring conservative Catholics? Effects of Pope Francis' encyclical on the US public opinion on climate change. Climatic Change, 139(3-4), 367-380.

Liu, H., \& Priest, S. (2009). Understanding public support for stem cell research: media communication, interpersonal communication and trust in key actors. Public Understanding of science, 18(6), 704-718.

Lupia, A. (2013). Communicating science in politicized environments. Proceedings of the National Academy of Sciences 110 (Supplement 3): 14048-14054.

Maibach, E., Leiserowitz, A., Roser-Renouf, C., Myers, T., Rosenthal, S., \& Feinberg, G. (2015). The Francis effect: how Pope Francis changed the conversation about global warming. Yale University and George Mason University. New Haven, CT: Yale Program on Climate Change Communication.

Malka, A., Krosnick, J. A., \& Langer, G. (2009). The association of knowledge with concern about global warming: Trusted information sources shape public thinking. Risk Analysis: An International Journal, 29(5), 633-647.

Malka, A., \& Lelkes, Y. (2010). More than ideology: Conservative-liberal identity and receptivity to political cues. Social Justice Research, 23(2-3), 156-188.

McCright, A. M., Dentzman, K., Charters, M., \& Dietz, T. (2013). The influence of political ideology on trust in science. Environmental Research Letters, 8(4), 044029 .

McCright, A. M., \& Dunlap, R. E. (2011). The politicization of climate change and polarization in the American public's views of global warming, 2001-2010. The Sociological Quarterly, 52(2), 155-194.

McCright, A. M., Charters, M., Dentzman, K., \& Dietz, T. (2016). Examining the effectiveness of climate change frames in the face of a climate change denial counter-frame. Topics in Cognitive Science, 8(1), 76-97.

Mildenberger, M., \& Tingley, D. (2017). Beliefs about climate beliefs: the importance of second-order opinions for climate politics. British Journal of Political Science, 129. doi: $10.1017 / \mathrm{S} 0007123417000321$

Miller, J. M., Saunders, K. L., \& Farhart, C. E. (2016). Conspiracy endorsement as motivated reasoning: The moderating roles of political knowledge and trust. American Journal of Political Science, 60(4), 824-844.

Motta, M. (2018). The Polarizing Effect of the March for Science on Attitudes toward Scientists. PS: Political Science \& Politics, 51(4), 782-788. 
Mullinix, K. J., Leeper, T. J., Druckman, J. N., \& Freese, J. (2015). The generalizability of survey experiments. Journal of Experimental Political Science, 2(2): 109-138.

Myers, T. A., Nisbet, M. C., Maibach, E. W., \& Leiserowitz, A. A. (2012). A public health frame arouses hopeful emotions about climate change. Climatic Change, 113(3-4), 1105-1112.

Nisbet, E. C., Cooper, K. E., \& Garrett, R. K. (2015). The partisan brain: How dissonant science messages lead conservatives and liberals to (dis) trust science. The ANNALS of the American Academy of Political and Social Science, 658(1), 36-66.

Nisbet, M. C. (2009). Communicating climate change: Why frames matter for public engagement. Environment: Science and Policy for Sustainable Development, 5l(2): $12-23$.

Nisbet, M. C., \& Myers, T. (2007). The polls - trends: Twenty years of public opinion about global warming. Public Opinion Quarterly, 71(3), 444-470.

O'Keefe, D.J. (1990). Persuasion: Theory and Research. Newbury Park, CA: Sage.

Oliver, J. E., \& Wood, T. J. (2014). Conspiracy theories and the paranoid style (s) of mass opinion. American Journal of Political Science, 58(4), 952-966.

Petty, R. E., \& Cacioppo, J. T. (1986). The elaboration likelihood model of persuasion. In Communication and persuasion (pp. 1-24). Springer, New York, NY.

Priest, S. H. (2001). Misplaced faith: Communication variables as predictors of encouragement for biotechnology development. Science Communication, 23(2), $97-110$.

Renn, O., \& Levine, D. (1991). Credibility and trust in risk communication. In Communicating risks to the public (pp. 175-217). Springer, Dordrecht.

Tversky, A., \& Kahneman, D. (1981). The framing of decisions and the psychology of choice. Science, 211(4481), 453-458.

Uscinski, J. E., Klofstad, C., \& Atkinson, M. D. (2016). What drives conspiratorial beliefs? The role of informational cues and predispositions. Political Research Quarterly, 69(1), 57-71.

Uscinski, J. E., \& Parent, J. M. (2014). American conspiracy theories. Oxford University Press.

Van Boven, L., Ehret, P. J., \& Sherman, D. K. (2018). Psychological barriers to bipartisan public support for climate policy. Perspectives on Psychological Science, 13(4), 492-507. 
van der Linden, S. (2015). The social-psychological determinants of climate change risk perceptions: Towards a comprehensive model. Journal of Environmental Psychology, 41, 112-124.

van der Linden, S., Leiserowitz, A., \& Maibach, E. (2019). The gateway belief model: A large-scale replication. Journal of Environmental Psychology, 62 (April 2019), 49-58 https://doi.org/10.1016/j.jenvp.2019.01.009.

Villar, A., \& Krosnick, J. A. (2011). Global warming vs. climate change, taxes vs. prices: Does word choice matter?. Climatic change, 105(1-2), 1-12.

Zhou, J. (2016). Boomerangs versus javelins: how polarization constrains communication on climate change. Environmental Politics, 25(5), 788-811. 
Table 1. Experimental Design and Predictions

\begin{tabular}{|c|c|c|}
\hline Condition & Treatment & Predicted outcome \\
\hline $\begin{array}{l}\text { National } \\
\text { Security } \\
(\text { No source }) \\
(N=184)\end{array}$ & $\begin{array}{l}\text { Some groups have recently argued that droughts and } \\
\text { flooding caused by climate change are a threat to the } \\
\text { security of the United States... }\end{array}$ & $\begin{array}{l}\text { National Security } \\
\text { Baseline }\end{array}$ \\
\hline $\begin{array}{l}\text { Military } \\
\text { Leaders } \\
(N=184)\end{array}$ & $\begin{array}{l}\text { A group of military leaders including generals and } \\
\text { homeland security officers have recently argued that } \\
\text { droughts and flooding caused by climate change are a } \\
\text { threat to the security of the United States... }\end{array}$ & $\begin{array}{l}\text { H1: increase the } \\
\text { frame's impact. }\end{array}$ \\
\hline $\begin{array}{l}\text { Democratic } \\
\text { Party Leaders } \\
(N=178)\end{array}$ & $\begin{array}{l}\text { A group of Democratic leaders in the House and Senate } \\
\text { have recently argued that droughts and flooding caused } \\
\text { by climate change are a threat to the security of the } \\
\text { United States... }\end{array}$ & $\begin{array}{l}\text { H3: increase } \\
\text { impact for Dems, } \\
\text { no effect on } \\
\text { Repubs. }\end{array}$ \\
\hline $\begin{array}{l}\text { Republican } \\
\text { Party Leaders } \\
(\mathrm{N}=183)\end{array}$ & $\begin{array}{l}\text { A group of Republican leaders in the House and Senate } \\
\text { have recently argued that droughts and flooding caused } \\
\text { by climate change are a threat to the security of the } \\
\text { United States... }\end{array}$ & $\begin{array}{l}\text { H3: increase } \\
\text { impact for } \\
\text { Repubs., no effect } \\
\text { on Dems. }\end{array}$ \\
\hline $\begin{array}{l}\text { Climate } \\
\text { Scientists } \\
(N=184)\end{array}$ & $\begin{array}{l}\text { A group of climate scientists have recently argued that } \\
\text { droughts and flooding caused by climate change are a } \\
\text { threat to the security of the United States... }\end{array}$ & $\begin{array}{l}\text { No prediction } \\
\text { relative to } \\
\text { baseline. }\end{array}$ \\
\hline $\begin{array}{l}\text { Environment } \\
(\text { No source }) \\
(N=192)\end{array}$ & $\begin{array}{l}\text { Some groups have recently argued that climate change } \\
\text { is a threat to the environment of the United States... }\end{array}$ & $\begin{array}{l}\text { Environmental } \\
\text { Baseline }\end{array}$ \\
\hline $\begin{array}{l}\text { Military } \\
\text { Leaders } \\
(N=187)\end{array}$ & $\begin{array}{l}\text { A group of military leaders including generals and } \\
\text { homeland security officers have recently argued that } \\
\text { climate change is a threat to the environment of the } \\
\text { United States... }\end{array}$ & $\begin{array}{l}\text { No prediction } \\
\text { relative to } \\
\text { baseline. }\end{array}$ \\
\hline $\begin{array}{l}\text { Democratic } \\
\text { Party Leaders } \\
(N=189)\end{array}$ & $\begin{array}{l}\text { A group of Democratic leaders in the House and Senate } \\
\text { have recently argued that climate change is a threat to } \\
\text { the environment of the United States. }\end{array}$ & $\begin{array}{l}\text { H3: increase } \\
\text { impact for Dems, } \\
\text { no effect on } \\
\text { Repubs. }\end{array}$ \\
\hline $\begin{array}{l}\text { Republican } \\
\text { Party Leaders } \\
(N=183)\end{array}$ & $\begin{array}{l}\text { A group of Republican leaders in the House and Senate } \\
\text { have recently argued that climate change is a threat to } \\
\text { the environment of the United States. }\end{array}$ & $\begin{array}{l}\text { H3: increase } \\
\text { impact for } \\
\text { Repubs., no effect } \\
\text { on Dems. }\end{array}$ \\
\hline $\begin{array}{l}\text { Climate } \\
\text { Scientists } \\
(N=184)\end{array}$ & $\begin{array}{l}\text { A group of climate scientists have recently argued that } \\
\text { climate change is a threat to the environment of the } \\
\text { United States. }\end{array}$ & $\begin{array}{l}\text { H2: increase the } \\
\text { frame's impact. }\end{array}$ \\
\hline
\end{tabular}


Figure 1. Message Source Effects Relative to No Source Appeal's Baseline

Threat to National Security

Military Source

Democrat Source

Republican Source

Climate Scientist Source

Threat to the Environment

Military Source

Democrat Source

Republican Source

Climate Scientist Source

\section{Politically Motivated}

Military Source

Democrat Source

Republican Source

Climate Scientist Source

\section{Support Laws}

Military Source

Democrat Source

Republican Source

Climate Scientist Source

\section{Climate Change is Happening}

Military Source

Democrat Source

Republican Source

Climate Scientist Source

\section{Scientific Consensus}

Military Source

Democrat Source

Republican Source

Climate Scientist Source

\section{Hoax}

Military Source

Democrat Source

Republican Source

Climate Scientist Source

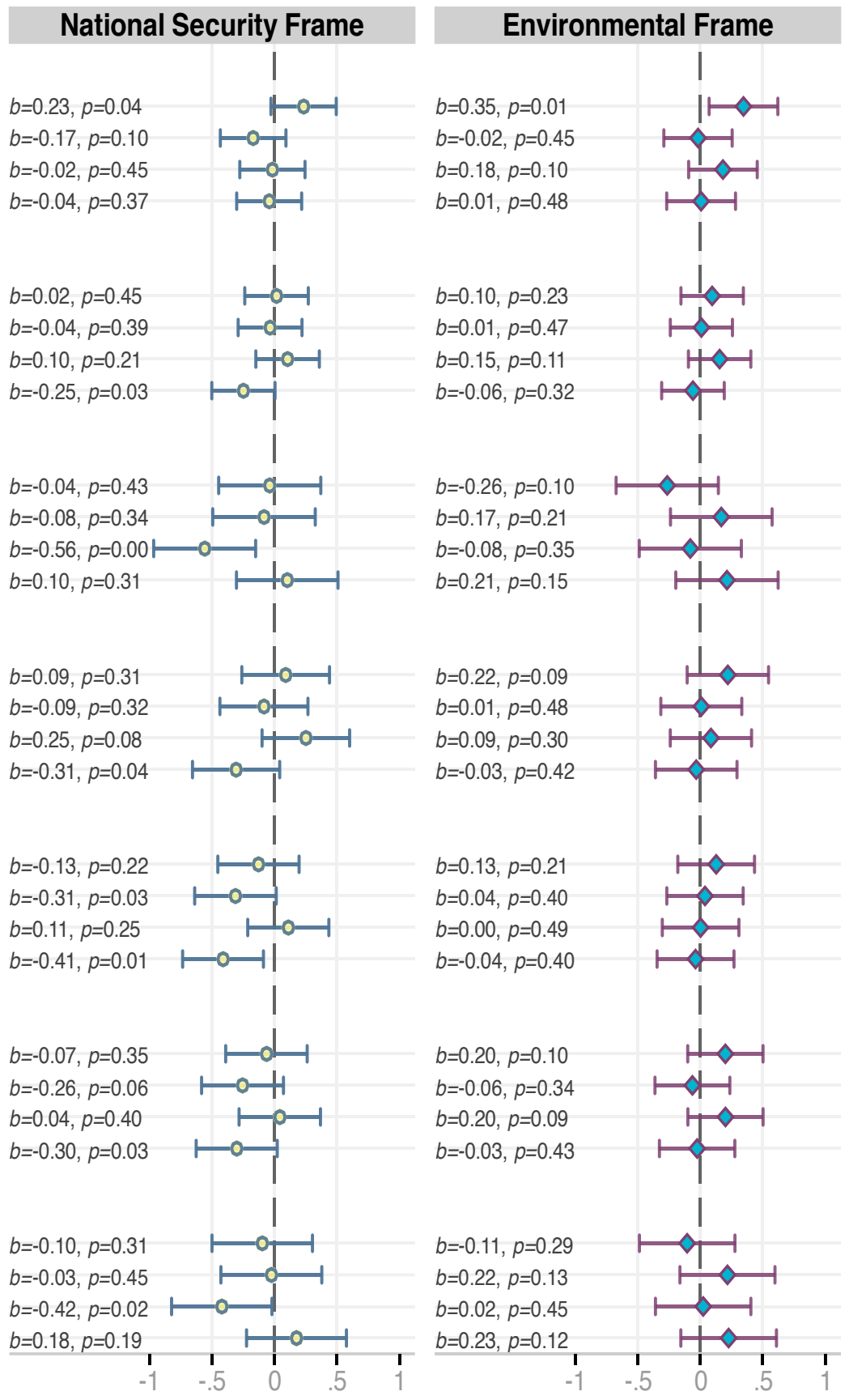


Figure 2: Treatment Effects by Partisan Sugroups

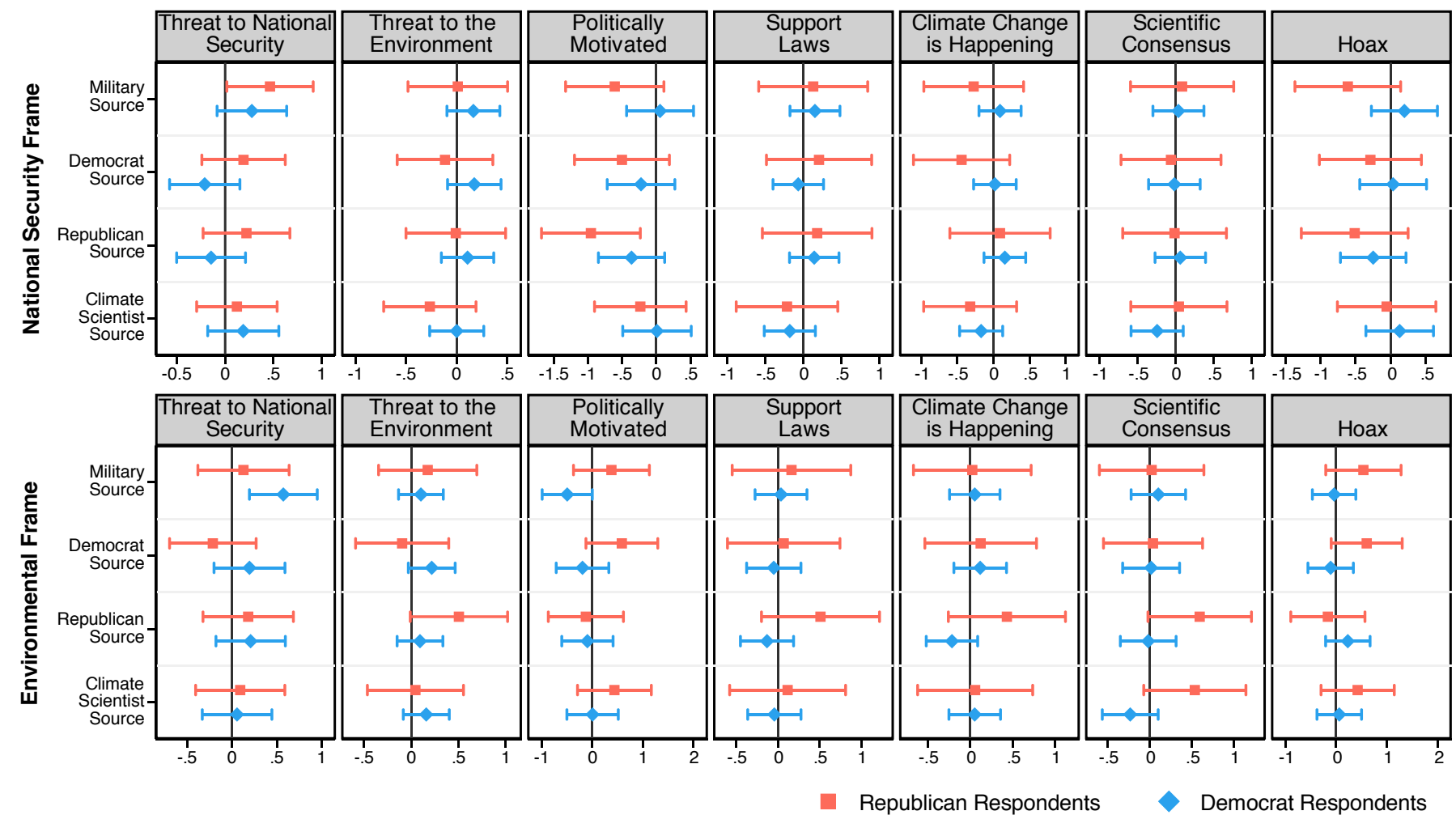

Note:Markers present coefficient estimates. Error bars represent the $95 \%$ confidence interval.

In the conditions recieving the National Security(Environmental) frame, Republican (Democrat) respondents
are compared to Republican (Democrat) respondents in the no-source National Security (Environmental) baseline. 
Table 2: Main Effects (Democrats only)

\begin{tabular}{|c|c|c|c|c|c|c|c|}
\hline National Security Frame & $\begin{array}{c}\text { Threat Nat. } \\
\text { Sec. } \\
(\text { Model 1) }\end{array}$ & $\begin{array}{c}\text { Threat } \\
\text { Env. } \\
\text { (Model 2) } \\
\end{array}$ & $\begin{array}{c}\text { Politically } \\
\text { Motivated } \\
\text { (Model 3) } \\
\end{array}$ & $\begin{array}{c}\text { Support } \\
\text { Laws } \\
(\text { Model 4) } \\
\end{array}$ & $\begin{array}{l}\text { Happening } \\
(\text { Model 5) } \\
\end{array}$ & $\begin{array}{c}\text { Scientific } \\
\text { Consensus } \\
(\text { Model 6) } \\
\end{array}$ & $\begin{array}{c}\text { Hoax } \\
(\text { Model 7) } \\
\end{array}$ \\
\hline \multirow[t]{2}{*}{ Military Leaders } & $0.28^{*}$ & 0.17 & 0.06 & 0.15 & 0.09 & 0.04 & 0.19 \\
\hline & $(0.18)$ & $(0.13)$ & $(0.25)$ & $(0.17)$ & $(0.15)$ & $(0.17)$ & $(0.24)$ \\
\hline \multirow[t]{2}{*}{ Democrat Leaders } & -0.21 & $0.18^{*}$ & -0.22 & -0.07 & 0.02 & -0.01 & 0.03 \\
\hline & $(0.19)$ & $(0.13)$ & $(0.25)$ & $(0.17)$ & $(0.15)$ & $(0.17)$ & $(0.24)$ \\
\hline \multirow[t]{2}{*}{ Republican Leaders } & -0.15 & 0.11 & $-0.36^{*}$ & 0.14 & 0.16 & 0.06 & -0.25 \\
\hline & $(0.18)$ & $(0.13)$ & $(0.25)$ & $(0.17)$ & $(0.15)$ & $(0.17)$ & $(0.24)$ \\
\hline \multirow[t]{2}{*}{ Climate Scientists } & 0.19 & 0.00 & 0.01 & -0.18 & -0.17 & $-0.24^{*}$ & 0.13 \\
\hline & $(0.19)$ & $(0.14)$ & $(0.25)$ & $(0.17)$ & $(0.15)$ & $(0.17)$ & $(0.24)$ \\
\hline \multirow{2}{*}{ Constant (No-Source Nat. Sec.) } & $3.33^{* * * *}$ & $4.38^{* * * *}$ & $2.41^{* * * *}$ & $6.43^{* * * *}$ & $6.47^{* * * *}$ & $6.31^{* * * *}$ & $1.84^{* * * *}$ \\
\hline & $(0.12)$ & $(0.09)$ & $(0.17)$ & $(0.11)$ & $(0.10)$ & $(0.12)$ & $(0.16)$ \\
\hline$N$ & 392 & 392 & 392 & 392 & 392 & 392 & 391 \\
\hline \multicolumn{8}{|l|}{ Environmental Frame } \\
\hline \multirow[t]{2}{*}{ Military Leaders } & $0.57^{* * * *}$ & 0.10 & $-0.49^{* *}$ & 0.04 & 0.05 & 0.10 & -0.04 \\
\hline & $(0.19)$ & $(0.12)$ & $(0.25)$ & $(0.16)$ & $(0.15)$ & $(0.16)$ & $(0.22)$ \\
\hline \multirow[t]{2}{*}{ Democrat Leaders } & 0.19 & $0.22^{* *}$ & -0.19 & -0.05 & 0.12 & 0.02 & -0.11 \\
\hline & $(0.20)$ & $(0.13)$ & $(0.26)$ & $(0.17)$ & $(0.16)$ & $(0.17)$ & $(0.23)$ \\
\hline \multirow[t]{2}{*}{ Republican Leaders } & 0.21 & 0.09 & -0.09 & -0.13 & $-0.22^{*}$ & -0.02 & 0.23 \\
\hline & $(0.20)$ & $(0.12)$ & $(0.26)$ & $(0.16)$ & $(0.15)$ & $(0.17)$ & $(0.22)$ \\
\hline \multirow{2}{*}{ Climate Scientists } & 0.06 & $0.16^{*}$ & 0.01 & -0.04 & 0.05 & $-0.23^{*}$ & 0.06 \\
\hline & $(0.20)$ & $(0.12)$ & $(0.26)$ & $(0.16)$ & $(0.15)$ & $(0.17)$ & $(0.22)$ \\
\hline \multirow[t]{2}{*}{ Constant (No-Source Env.) } & $3.22^{* * *}$ & $4.42^{* * *}$ & $2.55^{* * * *}$ & $6.45^{* * *}$ & $6.44^{* * *}$ & $6.26^{* * *}$ & $1.76^{* * *}$ \\
\hline & $(0.14)$ & $(0.09)$ & $(0.18)$ & $(0.11)$ & $(0.11)$ & $(0.12)$ & $(0.16)$ \\
\hline$N$ & 422 & 422 & 421 & 422 & 421 & 422 & 422 \\
\hline
\end{tabular}

Note: Cell entries are OLS coefficient estimates, with standard errors in parentheses. Conditions receiving the national security frame are compared to the NoSource National Security baseline; conditions receiving the environmental frame are compared to the No-Source Environmental condition. Asterisks represent one-tailed $p$-values. $* p<0.10 * * p<0.05 * * * p<0.01$ 
Table 3: Main Effects (Republicans only)

\begin{tabular}{|c|c|c|c|c|c|c|c|}
\hline National Security Frame & $\begin{array}{c}\text { Threat Nat. } \\
\text { Sec. } \\
\text { (Model 1) }\end{array}$ & $\begin{array}{c}\text { Threat } \\
\text { Env. } \\
\text { (Model 2) } \\
\end{array}$ & $\begin{array}{c}\text { Politically } \\
\text { Motivated } \\
\text { (Model 3) } \\
\end{array}$ & $\begin{array}{c}\text { Support } \\
\text { Laws } \\
(\text { Model 4) } \\
\end{array}$ & $\begin{array}{c}\text { Happening } \\
(\text { Model 5) } \\
\end{array}$ & $\begin{array}{c}\text { Scientific } \\
\text { Consensus } \\
(\text { Model } 6) \\
\end{array}$ & $\begin{array}{c}\text { Hoax } \\
(\text { Model } 7) \\
\end{array}$ \\
\hline \multirow[t]{2}{*}{ Military Leaders } & $0.47^{* *}$ & 0.01 & $-0.61^{* *}$ & 0.13 & -0.27 & 0.09 & $-0.61^{*}$ \\
\hline & $(0.23)$ & $(0.25)$ & $(0.37)$ & $(0.36)$ & $(0.35)$ & $(0.34)$ & $(0.38)$ \\
\hline \multirow[t]{2}{*}{ Democrat Leaders } & 0.19 & -0.11 & $-0.50^{*}$ & 0.20 & $-0.44^{*}$ & -0.06 & -0.29 \\
\hline & $(0.22)$ & $(0.24)$ & $(0.35)$ & $(0.35)$ & $(0.34)$ & $(0.33)$ & $(0.37)$ \\
\hline \multirow[t]{2}{*}{ Republican Leaders } & 0.22 & -0.01 & $-0.96^{* * *}$ & 0.18 & 0.09 & -0.01 & $-0.51^{*}$ \\
\hline & $(0.23)$ & $(0.25)$ & $(0.37)$ & $(0.37)$ & $(0.35)$ & $(0.35)$ & $(0.39)$ \\
\hline \multirow[t]{2}{*}{ Climate Scientists } & 0.12 & -0.26 & -0.23 & -0.22 & -0.32 & 0.05 & -0.06 \\
\hline & $(0.21)$ & $(0.23)$ & $(0.34)$ & $(0.34)$ & $(0.33)$ & $(0.32)$ & $(0.36)$ \\
\hline \multirow[t]{2}{*}{ Constant (No-Source Nat. Sec.) } & $2.09^{* * * *}$ & $3.16^{* * * *}$ & $4.82^{* * * *}$ & $4.55^{* * * *}$ & $4.91^{* * * *}$ & $4.85^{* * * *}$ & $4.07^{* * * *}$ \\
\hline & $(0.16)$ & $(0.17)$ & $(0.25)$ & $(0.25)$ & $(0.25)$ & $(0.24)$ & $(0.27)$ \\
\hline$N$ & 287 & 287 & 288 & 288 & 288 & 287 & 287 \\
\hline \multicolumn{8}{|l|}{ Environmental Frame } \\
\hline \multirow[t]{2}{*}{ Military Leaders } & 0.13 & 0.17 & 0.38 & 0.16 & 0.02 & 0.02 & $0.54^{*}$ \\
\hline & $(0.26)$ & $(0.26)$ & $(0.38)$ & $(0.36)$ & $(0.35)$ & $(0.32)$ & $(0.38)$ \\
\hline \multirow[t]{2}{*}{ Democrat Leaders } & -0.21 & -0.10 & $0.59^{*}$ & 0.07 & 0.12 & 0.04 & $0.60^{* *}$ \\
\hline & $(0.25)$ & $(0.25)$ & $(0.36)$ & $(0.34)$ & $(0.33)$ & $(0.30)$ & $(0.36)$ \\
\hline \multirow[t]{2}{*}{ Republican Leaders } & 0.18 & $0.50^{* * *}$ & -0.12 & $0.51^{*}$ & 0.43 & $0.60^{* * *}$ & -0.16 \\
\hline & $(0.26)$ & $(0.26)$ & $(0.38)$ & $(0.36)$ & $(0.35)$ & $(0.31)$ & $(0.37)$ \\
\hline \multirow[t]{2}{*}{ Climate Scientists } & 0.09 & 0.05 & 0.44 & 0.11 & 0.06 & $0.54^{* *}$ & 0.43 \\
\hline & $(0.25)$ & $(0.26)$ & $(0.37)$ & $(0.35)$ & $(0.34)$ & $(0.31)$ & $(0.37)$ \\
\hline \multirow[t]{2}{*}{ Constant (No-Source Env.) } & $2.48^{* * * *}$ & $3.08^{* * * *}$ & $4.24^{* * * *}$ & $4.76^{* * *}$ & $4.80^{* * * *}$ & $4.82^{* * * *}$ & $3.52^{* * * *}$ \\
\hline & $(0.18)$ & $(0.19)$ & $(0.27)$ & $(0.26)$ & $(0.25)$ & $(0.22)$ & $(0.27)$ \\
\hline$N$ & 274 & 274 & 271 & 273 & 273 & 274 & 273 \\
\hline
\end{tabular}

Note: Cell entries are OLS coefficient estimates, with standard errors in parentheses. Conditions receiving the national security frame are compared to the NoSource National Security baseline; conditions receiving the environmental frame are compared to the No-Source Environmental condition. Asterisks represent one-tailed $p$-values. * $p<0.10 * * p<0.05 * * * p<01$. 